University of Nebraska - Lincoln

DigitalCommons@University of Nebraska - Lincoln

Agronomy \& Horticulture -- Faculty Publications

Agronomy and Horticulture Department

$5-1990$

\title{
Registration of 15 Germplasm Lines of Grain Sorghum and Sweet Sorghum
}

Herman J. Gorz

United States Department of Agriculture

Francis A. Haskins

University of Nebraska-Lincoln, fhaskins@neb.rr.com

B. E. Johnson

University of Nebraska-Lincoln

Follow this and additional works at: https://digitalcommons.unl.edu/agronomyfacpub

Part of the Plant Sciences Commons

Gorz, Herman J.; Haskins, Francis A.; and Johnson, B. E., "Registration of 15 Germplasm Lines of Grain Sorghum and Sweet Sorghum" (1990). Agronomy \& Horticulture -- Faculty Publications. 231.

https://digitalcommons.unl.edu/agronomyfacpub/231

This Article is brought to you for free and open access by the Agronomy and Horticulture Department at DigitalCommons@University of Nebraska - Lincoln. It has been accepted for inclusion in Agronomy \& Horticulture -Faculty Publications by an authorized administrator of DigitalCommons@University of Nebraska - Lincoln. 


\section{REGISTRATION OF 15 GERMPLASM LINES OF GRAIN SORGHUM AND SWEET SORGHUM}

Four inbred lines (N97-N100) and 11 pairs of A and B (male-sterile and maintainer) lines (N101-N111) of sorghum [Sorghum bicolor (L.) Moench] were developed cooperatively by the USDA-ARS and the Nebraska Agricultural Research Division and were released in April 1989. The lines contain one or more traits that may have value for use in producing hybrids and/or conducting breeding and management studies. All A-lines have milo (A1) cytoplasm.

N97 (Reg. no. GP-246, PI 535782) is an R-line with reduced dhurrin content selected from the RP2B (2) population. A single $S_{1}$ family that was unusually low in dhurrin content was identified in Cycle 5 of the RP2B recurrent selection program for lower dhurrin content. Continued selection in three additional selfed generations resulted in the bulking of two $S_{4}$ families to make up the seed lot released as $\mathrm{N} 97$. The spectrophotometric assay for dhurrin (1) as measured by hydrocyanic acid potential ( $\mathrm{HCN}-\mathrm{p}$ ) of first leaves from 1-wk-old seedlings grown in the same test resulted in the following values for means and standard errors ( $\mathrm{mg} \mathrm{kg}^{-1}$ fresh weight, bulk of 10 seedlings per replication, three replications): N97-474 \pm 16 ; B-'Redlan'-1020 \pm 74 ; $\mathrm{B}-{ }^{-C} \mathrm{CK} 60-1045 \pm 72$. N97 has purple plant color and green midribs, reaches the heading stage in approximately $64 \mathrm{~d}$, is $135 \mathrm{~cm}$ in height at maturity, and has white caryopsis color.

N98, N99, and N100 (Reg. no. GP-247-GP-249; PI 535783-PI 535785) were derived from crosses made with the objective of transferring sweet sorghum germplasm into earlier-maturing lines with improved adaptation to growing conditions in the Central Great Plains. Each of the lines has purple plant color and green midribs and has been selfed more than six generations. N98 is a composite of four $\mathrm{F}_{6}$ lines from an initial cross of an experimental A-line [AN39 $\times$ (N4692-Rio) ${ }^{4}$ ] to 'Waconia' sweet sorghum, followed by a final cross to 'Fremont' forage sorghum. The following values were obtained in 1988 for days to heading, height at maturity, and Brix, respectively: $69,250 \mathrm{~cm}, 21 \%$. Caryopsis color is dark brown. N99 is an $F_{7}$ selection with light brown caryopsis color from a cross of Fremont forage sorghum $X$ 'Theis' sweet sorghum. Values in 1988 for days to heading, height at maturity, and Brix were $58,235 \mathrm{~cm}$, and $20 \%$, respectively. $\mathrm{N} 100$ is an $\mathrm{F}_{7}$ selection with light brown caryopsis color from a cross of Waconia $X$ 'Wray' sweet sorghum. Values for days to heading, height at maturity, and Brix in 1988 were $80,270 \mathrm{~cm}$, and $18 \%$, respectively.

N101, N102, and N103 (Reg. no. GP-250 to GP-252; PI 535786-PI 535788) are combine-height grain sorghums selected for lower HCN-p from the RP2B population. N101 and N103 have had more than six crosses of the cytoplasmic male-sterile to the recurrent male parent, and the male also has been selfed more than six generations. N102, on the other hand, has had only three crosses to the male parent and four self-pollinations of the male. N101 and N102 have green midribs, purple plant color, white caryopsis color, and are approximately $120 \mathrm{~cm}$ in height. N103 has brown midribs (obtained by pollinating a low- $\mathrm{HCN}$-p genetic male-sterile RP2B selection with B-Redlan $b m r-6$ ), averages $150 \mathrm{~cm}$ in height, has purple plant color and white caryopsis color, and is 4 or $5 \mathrm{~d}$ later in maturity than N101 and N102. The spectrophotometric assay for $\mathrm{HCN}-\mathrm{p}$ for first leaves from 1wk-old seedlings grown in the same test resulted in the following values for means and standard errors $\left(\mathrm{mg} \mathrm{kg}^{-1}\right.$ fresh weight, bulk of 10 seedlings per replication, six replications for N101 and N103; three replications for Redlan and CK60): N101-442 $\pm 40 ;$ N103-677 \pm 62 ; B-Redlan-1020 \pm 74 ; and B-CK60-1045 \pm 72 . N102 has not been assayed for $\mathrm{HCN}$-p but the immediately preceding generation had a mean value of $408 \pm 50$ for two replications. These inbreds have not been tested in hybrid combinations with sudangrass but are potentially useful for producing low $\mathrm{HCN}-\mathrm{p}$ sorghum-sudangrass hybrids or as a source of grain sorghum germplasm with reduced $\mathrm{HCN}$-p for use in breeding programs.

N104, N105, N106, and N107 (Reg. no. GP-253-GP-256; PI 535789-PI 535792) represent the four phenotypic combinations that resulted from a cross of bloomless Redlan (BRedlann $\left.b m_{1}\right) \times$ brown midrib Redlan (B-Redlan $b m r-6$ ). Thus, N104 has bloom and green midribs. N105 has bloom and brown midribs, N106 is bloomless with green midribs, and N107 is bloomless with brown midribs. The heights $(\mathrm{cm})$ of $\mathrm{N} 104, \mathrm{~N} 105, \mathrm{~N} 106$, and $\mathrm{N} 107$ are 120, 115, 130, and 109, respectively. Plants of all four phenotypes, identified in a single $\mathrm{F}_{4}$ family heterozygous for both bloom and brown midrib, were selfed for two additional generations to identify those plants within each phenotype that were homozygous for both traits. Homozygous $F_{6}$ plants of each phenotype were then crossed to A-Redlan to begin the development of A- and B-lines. A total of five crosses were made to each recurrent parent and the males were advanced to the $F_{8}$ generation. The four lines have purple plant color, light brown caryopsis color, and are similar to Redlan except for the presence of the bloomless and/or brown midrib traits and 
Table 1. Brief description of inbred lines N108, N109, N110, and N111.

\begin{tabular}{llccccc}
\hline Inbred & Pedigree & $\begin{array}{c}\text { Bloom Height Plant } \\
(\mathrm{d})\end{array}$ & $\begin{array}{c}\text { Caryopsis } \\
\text { (cm) }\end{array}$ & $\begin{array}{c}\text { Brix } \\
\text { color }\end{array}$ & color & $(\%)$ \\
\hline N108† Saccharum-Sorgo & & 75 & 162 & Tan & Lt. Tan & $17 \pm 0.5$ \\
N109 & White Collier $\times$ Grain & & & & & \\
& $\quad$ Sorghum Line & 75 & 143 & Purple White & $19 \pm 0.4$ \\
N110 & Red $\times$ & 73 & 256 & Purple Brown & $20 \pm 0.2$ \\
N111 & Waconia & 75 & 260 & Purple Brown & $20 \pm 0.2$ \\
\hline
\end{tabular}

$\dagger$ Has wrinkled seeds.

should be of value for the production of hybrids, as a source of germplasm in breeding programs, and for studies in which the bloomless and brown midrib traits are examined for their effects on forage quality and other agronomic traits.

N108, N109, N110, and N111 (Reg. no. GP-257-GP-260; PI 535793-PI 535796) were developed with the objective of obtaining sweet sorghum female parents. A brief description of these inbred lines is presented in Table 1. Some additional entries, grown in the same nursery as these inbreds, had the following Brix values: B-Redlan-8.3 \pm 0.07 , B-CK60-12.6 \pm 0.32 , 'Sart'-16.2 \pm 0.50, 'Rio' $-17.6 \pm 0.34$, 'Williams'$19.4 \pm 0.70$, 'Brandes'-20.4 \pm 0.32 , Wray-21.3 \pm 0.07 , and 'Keller' $-22.0 \pm 0.12$. Each of the four inbreds has green midribs and all A-lines have milo (A1) cytoplasm; there have been at least six crosses of the cytoplasmic male-sterile to the recurrent parent, and each male parent has been selfed at least six generations. N108 and N109 have not been evaluated in hybrid combinations, but preliminary evaluation of N110 and N111 revealed that they make productive hybrids when crossed to sweet sorghum males. These inbred lines may be useful for producing sweet sorghum hybrids or as a source of germplasm for breeding programs.

Seed of inbreds N97 to N111 will be maintained and distributed by the Department of Agronomy, University of $\mathrm{Ne}$ braska, Lincoln, NE 68583. It will be available in germplasm quantities only. Recipients of seed are asked to make appropriate recognition of the source of the germplasm if it should contribute to the development of a new germplasm, parental line, cultivar, or hybrid.

H. J. Gorz,* F. A. Haskins, AND B. E. Johnson (3)

\section{References and Notes}

1. Gorz, H.J., W.L. Haag, J.E. Specht, and F.A. Haskins. 1977. Assay of phydroxybenzaldehyde as a measure of hydrocyanic acid potential in sorghums. Crop Sci. 17:578-582

2. Ross, W.M., S.D. Kindler, H.L. Hackerott, T.L. Harvey, A. Sotomayor, O.J. Webster and K.D. Kofoid. 1977. Registration of RP1R and RP2B sorghum germplasm. Crop Sci. 17:983.

3. H.J. Gorz (retired), USDA-ARS; and F.A. Haskins (retired) and B.E. Johnson, Dep. of Agronomy, University of Nebraska, Lincoln, NE 68583. Cooperative investigations of the USDA-ARS and the Nebraska Agric. Res. Division. Published as Journal Series Paper no. 8929, Nebraska Agric. Res. Division. Registration by CSSA. Accepted 31 Aug. $1989{ }^{*}$ Corresponding author.

Published in Crop Sci. 30:762-763 (1990). 